\title{
The Avant-Garde Artist: Between the All-Too-Human and the Inhuman. Towards an Anthropological Aesthetics
}

Magdalena Popiel 
Magdalena Popiel

\section{The Avant-Garde Artist: Between the All-Too-Human and the Inhuman. Towards an Anthropological Aesthetics}

DOI: 10.18318/td.2015.en.1.7

The whole man is an author. Paul Valéry

\section{Anthropological Aesthetics}

"There really is no such thing as Art. There are only artists"1 - states Erich Gombrich at the beginning of one of his works. This is neither an obvious nor a universally accepted claim within the field of contemporary art history, but it does exhibit an interesting coherence with the aesthetic thinking prevalent in various areas of the humanities.

During the course of the twentieth century philosophy of art has put the aesthetic object in the center of its interest. Questions addressing the work of art have been placed from within different methodologies, and have outlined the main investigatory horizon of aesthetics. This rather restrictive way of defining the investigative field coincided with the proposition of scientific objectivism, especially among the formalist branches within aesthetics. Literary criticism's abandonment of the nineteenth-century biographism and psychologism resulted in peculiar stance of resentment that in turn led to the resolute proposition of the emancipation of the work of art. Reception of art framed in terms of interpersonal

1 Ernst Gombrich, The Story of Art (London: The Phaidon Press, 1950), 5.
Magdalena Popiel professor at the Department of Anthropology of Literature and Cultural Studies in the Faculty of Polish Studies at the Jagiellonian University. She is engaged in the study of the aesthetics of modernism, the theory and history of the novel and Italian literary criticism. Author of the following books: Historia i metafora (1989), Oblicza wzniosłości. Estetyka powieści młodopolskiej (1999), Wyspiański. Mitologia nowoczesnego artysty (2007, 2009); author of chapters published in Volume 1 and 2 of Kulturowa teoria literatury. A member of the editorial board of "Przestrzenie Teorii". Chairwoman of the International Association of Polish Studies. Contact: mpopiel@ interia.pl 
relations has been deemed naive by professionals. The odium incurred by the artist resulted in his exclusion from any serious discourse of art, as he became someone who bears the least rights to speak about his creations. Paradoxically the more the artist rose in the ranks of public life, and was shaped by means and institutions of mass culture into a figure of authority, also within non-artistic fields, the more steadfast was academic aesthetics at silencing his voice or treating him merely as a dubious witness to the artistic process ${ }^{2}$.

An analysis of the work of art that neglected the persona of its creator ceased to be the predominant analytical procedure with the weakening of the key concepts of the logocentric worldview. Concurring with Nietzsche's claim that the control of science is possible only by means of art $^{3}$, postmodernism has crowned aesthetics as "first philosophy" and in many ways dignified the terms derived from the realm of art. The whole Areopagus of postmodern philosophers: Lyotard, Welsch, Baudrillard, Sloterdijk, Kamper, has underscored, by divergent means, the single conviction that "postmodern thinking is defined by aesthetics"4. No wonder then that with such a principle at its base the category of an artist became a kind of a founding myth within this field. It is notable that the concept of a modernist artist became a point of reference for defining the condition of the participants of post-modern culture. In the views and creative actions of the artists of the great avant-garde and the neo-avant-garde Lyotard and Welsch sought the anticipation of late twentieth-century philosophy. The modernist artist and the post-modernist philosopher share an experimental mindset; a propensity for repetitive trials, and an aptitude for subverting and exposing the universalizing rules of metanarratives and aesthetic systems, with the hope of ensuring pluralism and freedom. According to this view, the avant-garde artist became a prefiguration of the post-modern man, who through the "increase of being and the jubilation which result from the invention of new rules of the game"5 creates himself and the world.

2 Literary theory in the 2oth century, as is well known, was rather inclined to annex the deep analysis of the reception of a work of art in the form of German aesthetics of reception and the Anglo-American reader response theory.

3 Friedrich Nietzsche, Unpublished Writings from the Period of Unfashionable Observations, trans. Richard T. Gray (Stanford: Stanford University Press, 2000), 13.

4 Wolfgang Welsch, "Narodziny filozofii postmodernistycznej z ducha sztuki modernistycznej" in: Odkrywanie modernizmu, ed. Ryszard Nycz, (Kraków: Universitas, 1998), 455.

5 Jean-Francois Lyotard, "Answering the Question: What is Postmodernism?" in The Postmodern Condition: A Report on Knowledge, trans. Regis Durand, vol. 10 of Theory and History of Literature ed. Wlad Godzich and Jochen Schulte-Sasse, (Minneapolis: University of Minnesota Press, 1984), 80. 
The concept of the artist occupies an equally central space within contemporary neopragmatism. Richard Shusterman, who considers himself a descendant of the aesthetic thought represented by such thinkers as John Dewey and Nelson Goodman, opposes the elitist and fetishistic concept of art that is fixated on the artistic object. The author of Pragmatist Aesthetics methodically exposes the deceptiveness of barriers that separate high art from popular art in contemporary culture (this also holds true for the culture of past ages, i.e. of Antiquity or the Renaissance). A hallmark of post-modern times can be found in the highly symbolic dimension bestowed by culture upon the rapper, who in his art is part dancer, part poet, and part philosopher ${ }^{6}$. Richard Rorty explains the rise of the artist's prominence by referring to traditional, archetypal models of personality:

The point is that the priest, the philosopher or the scientist are accustomed to ascribing to themselves the knowledge that stands in a certain relation to the universe, accurately presenting it. But if we make the poet or artist to be the exemplary models of human existence, then the point is no longer about thinking about them in terms of correctness about the universe. They are considered to have the courage and talent to create themselves, to be their own masterpiece; this shift in relation to modernity culminates in conceding: do not assume that knowledge is the essence of human existence, self-creation is important for man, not knowledge; let the poet embody the human abilities to the highest degree... ${ }^{7}$.

In Rorty's view the artist, defined as the "paradigm of human accomplishment", becomes the pinnacle of post-modern philosophy of man that has placed in its center a mythologized concept of the creative genius.

These philosophical considerations resonate through contemporary anthropological and sociological thinking that is preoccupied with the artist as its subject. If we ascertain that what we are witnessing nowadays is a process of the coming of a society of individuals (Norbert Elias), then, as the French anthropologist Daniel Fabre claims, it is the artist who is given the title of

6 Richard Shusterman, Pragmatist Aesthetics: Living Beauty, Rethinking Art (Lanham: Rowman and Littlefield, 2000), 139-236.

7 This fragment comes from an unpublished interview with Richard Rorty that was conducted by Lech Witkowski, and was made available by Lech Witkowski to Tadeusz Szkołut for use in his paper: Tadeusz Szkołut "O perspektywach estetyki w dobie kultury postmodernistycznej" in Sztuka i estetyka po awangardzie a filozofia postmodernistyczna, ed. Anna Zeidler-Janiszewska (Warszawa: Instytut Kultury, 1994), 197. The interview was also published in: Lech Witkowski "Liberalizm, lewica i mądrość powieści" in Edukacja wobec sporów o (po)nowoczesność (Warszawa: Instytut Badań Edukacyjnych, 1997). 
"the avant-garde of modern individualism"8. The Culture of Narcissism, in the course of becoming a vital component of contemporary culture, acquired several descriptive characterizations in the narratives of modernist artists 9 A historical analysis of the cult of artists in modern times that touches upon the topics of sacralization and desacralization of the artist, as well as his embodiment and disembodiment, demands positing a series of new questions that address the ways in which a creative individual functions within the confines of cultural institutions, and the collective imagination. Popular culture's rise to prominence created conditions for the transference of the aura from works of art onto the artists themselves (Walter Benjamin mentioned this phenomenon in his essay The Work of Art in the Times of Mechanical Reproduction, after he first noticed it in the moving pictures of the thirties). This process was assisted by the proliferation of new genres in literature, journalism and film (interview-fleuves or film biographies) and the forms of public life (festivals, contests, author readings), which allowed the artist's voice to be heard.

It seems that these voices, coming from different corners of the humanities and culture, signal a need for a project of a new interdisciplinary a n thropological aesthetics, one which by combining different investigatory perspectives (such as artist aesthetics, artist anthropology, literary anthropology, psychology of art, sociology of art, history of ideas) would shed a new light upon the understanding of the artist as an aesthetic category. Akin to philosophical anthropology, which Odo Marquard characterizes as philosophy speaking of "man human and all-too-human"10, the term possesses certain tautological traits; as it is evident that from its very inception traditional aesthetics exhibited an interest in the "human world". Nevertheless it was predominantly focused, in the area of aesthetica artificialis, on manufactured objects, artifacts. Anthropological aesthetics would reverse this point of view, it would bring to the foreground the creative human being, and describe its existential condition.

The primary interest of anthropological aesthetics is 'a r tists' a e sth e t i c s', which was previously neglected by twentieth-century theory of

8 Paweł Rodak, "Czym jest antropologia literatury? Pytanie o początek literatury. Rozmowa z Danielem Fabre" Teksty Drugie 4 (2009): 256. Compare: Norbert Elias, Involvement and Detachment (Oxford: Blackwell, 1987); Norbert Elias, The Civilizing Process: Sociogenetic and Psychogenetic Investigations (Oxford: Blackwell, 2000); Norbert Elias, Mozart: Portrait of a Genius (Cambridge: Polity, 1993).

9 Christopher Lasch, The Culture of Narcissism: American Life in an Age of Diminishing Expectations (London: Warner Books, 1979); Richard Sennett, The Fall of Public Man, (New York: Knopf, 1977).

Odo Marquard, Szczęście w nieszczęściu (Warszawa: Oficyna Naukowa, 2001), 158. 
art. Artists' aesthetics was mainly perceived as an auxiliary discipline for other aesthetic endeavors: those oriented in philosophical or scientific directions, as well as those serving mainly ideological purposes. It was tasked with providing a base of material for more systematic and organized research, mainly through the edition and analysis of artistic works, which were mainly viewed as a source of facts and knowledge about the author's life. Already in the second half of the twentieth century this traditional approach ceased to be sufficient. It is made evident by the evolution of the theoretical thought of Stefan Morawski1", one of the foremost Polish philosophers working in the sub-discipline of aesthetics. At first he believed that the artists' aesthetics is tasked with "discerning the theoretical principles, which in a syncretic juxtaposition would allow to draw a rough picture of new artistic aesthetics of our times, and its connections to and disconnections from academic aesthetics"12. In this case the rationale behind using texts of artists was either to form a certain aesthetic theory on their basis or to reconstruct a history of artistic schools and doctrines. In the Postscript to the 1989 edition of Main Aesthetic Schools the author confessed that if he was to follow his own proclivities then he would write a history of philosophers working in the field of aesthetics, these would include above all such "thinkers-visionaries" as Berdyaev, Bloch, Heidegger, Adorno, Ricoeur, Read, Maritain and Dewey. Morawski's late confession to his predilection for investigating the individualities of the "lonesome riders" of aesthetics is at odds with his previous methodological preferences. The thinker adds that if he was to write a historical synthesis of twentieth-century aesthetics anew then he would give much more prominence to considerations on the nature of artists' aesthetics: "In my opinion this is the most prominent phenomenon in the light of contemporary cultural shifts"13. It can be presumed that this idea might have been one of those projects, transcending the boundaries of traditional aesthetics, which the thinker hoped to, but did not, complete during his lifetime.

The project of anthropological aesthetics opens before artists' aesthetics a possibility of a dynamic and substantial reorientation of research, bringing forward three distinct sets of problems.

11 It is worth mentioning that Władysław Tatarkiewicz, to whom the discipline is indebted for introducing the distinction between implicite and explicite aesthetics, in his summary of the threevolume synthesis pointed out that his history of aesthetics was mostly a history of individuals, writers and artists (Consult the introduction to: Władysław Tatarkiewicz, History of Aesthetics: Vol. I Ancient Aesthetics, trans. Adam and Ann Czerniawski (The Hague: Mouton, 1970). turze, 1992), 13.

13 Ibid., 114 . 
First of all, while restoring the voices to artists from diverse artistic fields, it is worthwhile to analyze their statements with the tools provided by contemporary narrative the ory. The primary material is obtained from autobiographical accounts found within private documents: journals, diaries, letters, memoirs. An equally prominent place is held by writings that deal with art itself in the form of manifestos, proclamations and essays, in which the artist takes up the role of a literary, artistic, music, or theater critic. A particularly important sphere is constituted by the opinions of artists about artists that often take on the shape of portraits into which a self-portrait is inserted. And additional resources can be found within artists' biographies, in all their culturally sanctioned variety: from the scientific to the popular, from strictly factual to fictionalized accounts; ones personally engaged with the subject, or constructed as impersonally objective; those that make their subject a familiar person and those that make it a mythical creature. Finally the attention of anthropological aesthetics turns to those works that make up a specifically structured system, wherein artifacts traditionally associated with a distinct concept of an artist, such as a novel about an artist or self-portraits, are of utmost importance.

The borders delineating these investigatory fields are blurry; the subject emerging from these three forms of activity is a sylleptic construct, ambiguous and shimmery, it juggles social roles, switching masks of fiction and authenticity. Autobiographies - we are all well aware of it - are creations of language, narrative and the world; and works of fiction all possess a more or less noticeable autobiographical dimension.

The goal would be to distinguish such an anthropological aspect of the 'discourse of the self' that would allow, in the words of Ryszard Nycz, the perception of texts as: "indispensable testimony to the presence and evolution of personality patterns that are dominant in the culture of a particular time and place, and by means of which contemporaries used to describe their own identity"14. The image of the artist that emerges in the light of anthropological aesthetics is a result of the interplay of tensions between a certain human condition and the concept of art that constitutes itself within the boundaries of narrative identity. The constitution of the subject and the creation of identity plays out to the tune of a specific narrative rhythm: a $\mathrm{narcis}$ is tic tale, aimed towards self-discovery, and an eccentric tale, aimed towards creation.

Following Marquards theory, which attempts to restore luster to the tarnished philosophical anthropology, in the form given to it by Helmuth Plesner (Die Stufen des Organischen und der Mensch 1928) and Arnold Gehlen (Der Mensch

14 Ryszard Nycz, Literatura jako trop rzeczywistości (Kraków: Universitas, 2001), 58. 
1940), it is worth introducing the theme that the author of the Glückim Unglück names the "skeptic theme of coming round":

A human - as it [philosophical anthropology] shows is not a triumphant being, but a primarily compensating one: he is not the "crowning" - but as Stanisław Jerzy Lec said - "the thorny crown of creation". Man is not simply an acting being, but also a sensing one; the better part of him consists more of what he experienced than of what he accomplished, that is why man is made up of his stories ${ }^{\mathbf{1 5}}$.

This important conviction, which echoes many schools of the twentiethcentury philosophy of man can be considered an important premise for the project of anthropological aesthetics, which will describe the artist by means of his own stories: those that he tells to himself and those that are being told about him. Only by such means can an image be formed that will have the capability of encompassing both the sphere of actions and that of sensations.

The artists' narratives are double-layered also in another sense. They are, as George Steiner notices in The Broken Contract, "narratives of formal experience". They tell stories of thought"16. By referring to such texts as the treatise of Pseudo-Longinus on the "sublime", Coleridge's Biography, Ruskin's Modern Painters, Proust's Contre Saint-Beuve, he argues that they are a kind of "mythologies of the comprehensible", "fables of comprehension" - and the hermeneutical thinking is in the case of an artist permeated with creative energy. Energy that flows from within art itself, which was described by Friedrich Nietzsche in these words:

art is by its nature affirmation, a blessing, a deification of being...

- What is the meaning of pessimistic art? ... Isn't it a contradiction in terms? [...] in case of an artist representing horrible and disturbing things is in itself a manifestation of the instinct of power and control: he does not fear them. There is no pessimistic art... Art only affirms ${ }^{\mathbf{1 7}}$.

And this is the second crucial reference point for anthropological aesthetics. It addresses the discipline of poetics, which after Aristotle is conceived as the theory of human action. This new perspective would entail adopting the view presented by Giorgio Agamben:

\footnotetext{
15 Marquard, Szczęście, 156-157. 
The central experience of poiesis, production into presence, is replaced by the question of the "how", that is, of the process through which the object has been produced. In terms of the work of art, this means that the emphasis shifts away from what the Greeks considered the essence of the work - the fact that in it something passed from nonbeing into being, thus opening the space of truth $(\dot{\alpha}-\lambda \dot{\eta} \theta \varepsilon 1 \alpha)$ and building a world for man's dwelling on earth - and to the operari of the artist, that is, to the creative genius and the particular characteristics of the artistic process in which it finds expression ${ }^{\mathbf{1 8}}$.

According to Agamben, the idea of genius, and the creative process, introduces to contemporary society a vision of a real openness to experience, that manifests itself not through the framework of heteronomous relations, but through a self-identifying space of possibility. The constant confrontation with endless potentiality causes the self to become capable of infinite creativity. The idiosyncrasy of Agamben's claim that art after Duchamp has lost its power of poiesis becomes evident through his search for an ideal work of art in Titian's The Three Ages of Man and the analysis of this work that fills the last pages of his work Aperto.

And finally the third referential sphere for anthropological aesthetics results directly from its setting between anthropocentrism and its negations. The idea of a genius constitutes one of the focal points within this area. Considerations on the nature of individual genius reach far beyond the realm of art itself, but they have a notably prolific representation in the aesthetic tradition. Furthermore, a multitude of ideas introduced in the humanities at the turn of the twentieth and the twenty-first century is reason enough to revisit this subject ${ }^{19}$.

Julia Kristeva in her inspiring book on Female Genius defines this central term this way:

Let us agree here to use the term "genius" to describe those who force us to discuss their story because it is so closely bound up with their creations, in the innovations that support the development of thought and

18 Giorgio Agamben, The Man Without Content, trans. Georgia Albert (Stanford: Stanford University Press, 1999), 70.

19 See i. a.: Harold Bloom, Genius: A Mosaic of One Hundred Exemplary Creative Minds (New York: Warner Books, 2002); Giorgio Agamben, Profanations (New York: Zone Books, 2007); Paul Ricoeur, The Course of Recognition (Cambridge: Harvard University Press, 2005); Bernard Smith, The Death of the Artist as Hero: Essays in History and Culture (Melbourne: Oxford University Press, 1988). 
beings, and in the onslaught of questions, discoveries, and pleasures that their creations have inspired. In fact, these contributions touch us so intimately that we have no choice but to moor them in the lives of their authors ${ }^{20}$.

The paradox contained within Kristeva's apparently obvious thesis, defining genius by its compulsive demand for becoming the object of a story, can be traced to a fundamental claim. It states that the true legitimization of a genius is based upon the work itself, but also on the doxa, the public opinion that applies its own criteria in the process of validating and affirming him.

Kristeva's trilogy, honoring three women: Hannah Arendt, Melanie Klein and Colette, is an interesting attempt at revitalizing the concept of genius. Although the central investigatory focus on the term's transformations is governed by the concept of gender, many of the analyzed themes concern the general idea of an exceptional individuality.

Kristeva perceives Arendt's genius as unity of work and action, the modern phronesis is accomplished by responsible action. An extraordinary synthesis of the theories of Arendt's three teachers: Aristotle, Augustine and Heidegger, has inspired her theory of the human being, one which equates thought, action and speech. Nevertheless a sole heroic act of a genius - Kristeva claims does not make the action magnificent. The action becomes heroic only when it demands thoughtful consideration. And what might be even more important: the action itself cannot be encapsulated in a single petrifying word, it should be acted out, recreated each and every time: "only then can muthos remain energeia"21. The process of creating a genius, as illustrated by Kristeva, leads from a "narrated acti o n" to an "act ing narrative". This is why the therapeutic role of the idea of genius becomes so important in the modern world:

Suffice is to say that "genius" is a therapeutic invention that keeps us from dying from equality in a world without a hereafter. [...] In our day it would appear the word 'genius' stands for paradoxical occurrences, unique experiences, and remarkable excess that manage to pierce through an increasingly automated world. The troubling, even formidable, emergence of such phenomena helps us understand the meaning of human existence. [...] my geniuses displayed qualities that, while no doubt exceptional, can be found in most of us. And they (the geniuses, which in this case are three

20 Julia Kristeva, Hannah Arendt, trans. Ross Guberman (New York: Columbia University Press, 2001), XI.

21 Ibid., 74 . 
female geniuses) did not hesitate to make mistakes and to let us know their limitations. What distinguishes these geniuses from us is simply that they left us to judge a body of work rooted in the biography of their experience. The work of a genius culminates in the birth of a subject ${ }^{22}$.

For this reason the discourse reintroducing and renewing the idea of genius becomes an important voice calling for the safeguarding of subjectivity in a world of progressive unification and anonymity.

Summarizing, as a discipline anthropological aesthetics refers to several areas of research and determines three major investigatory fields:

1. the poetics of narrative, that determines the artist's model personality;

2. the experience of poiesis, that defines the boundaries of human potential;

3. the problem of genius: an exceptional individual who creates and is created in the reconstructive ritual of storytelling.

In the subsequent part of this article I will address one of the themes of anthropological aesthetics which focuses on the figure of the modern artist. Through the gradually constricting analytical perspective certain mechanisms of creation and self-creation of the avant-garde artist will be brought to light.

\section{Genius - the All-Too-Human and the Inhuman}

Considerations on the nature of the creative individual have become much more significant and dynamic in modern times. The humanist tradition has undergone critical revision, so has the idea of genius, as one of the cornerstones of modern anthropocentrism.

Antiquity did not possess any concept of an ingenious artist, although many ideas expressed in the works of Plato, Aristotle or Horace have influenced the subsequent formation of the category of an exceptional creative individual. The question of the roots of poetic inspiration and the theory of the divine poetic madness, which can be traced to Plato's Phaedrus, will come to inspire philosophers, critics and the artists themselves for eternity. However, the nascence of the idea of genius came in the time of the Renaissance; aesthetic deliberations on the subject focused on a cosseted group of favorite heroes: within the visual and fine arts - Leonardo da Vinci, in literature - William Shakespeare. The Renaissance vision of the poet as alter deus will evolve into a figure of a divine "architect in the kind" 23 . In the eighteenth

22 Kristeva, Arendt, X.

23 Meyer Howard Abrams, The Mirror and the Lamp: Romantic Theory and the Critical Tradition (Oxford: Oxford University Press, 1971), 201. 
century numerous and in-depth studies on the concept of genius have been inspired by anthropological philosophy and by the aesthetics which was being developed at that time. The theory of two kinds of genius: the natural and the "formed", was at first purely typological, not qualitative. Joseph Addison talks of natural geniuses as those who are "the prodigies of mankind, who by the mere strength of natural parts, and without any assistance of art or learning have produced works that were the delight of their own times, and the wonder of posterity" - and those of the other kind - "the second class of great geniuses are those that have formed themselves by rules, and submitted the greatness of their natural talents to the corrections and restraints of art"24. Over the course of time the first kind of exceptional individuals has become a sum total of human capabilities, an embodiment of human wholesomeness that was cultivated throughout the nineteenth-century European idealism. The artist became only one of numerous aesthetic categories that have been placed at the foundations of modern philosophy in its quest for the restitution of the unity of mind, human existence and society ${ }^{25}$. The concept of an ingenious creator has come to act as a lightning rod in the concurrent struggle with the philosophical premises of unity, completeness and wholeness.

What seems especially interesting from the perspective of twentiethcentury art, and its noticeably anthropocentric tendencies, is the fact that from the very beginning the discourse of genius encompasses the relation of that which is all-too-human with that which is inhuman. This protean face of a genius becomes crystal clear in the organicistic theories of the creative process. This inhuman character has been fervently underscored by poets well before Eliot. John Keats has described the poet's nature in such words:

As to the poetic character itself, it is not itself: it has no self - it is everything and nothing. The Sun, the Moon, the sea, and men and women who are creatures of impulse, are poetical and have about them an unchangeable attribute - the poet has none: no identity ${ }^{\mathbf{2 6}}$.

24 James Addison "There is no character..." [No. 160, Monday, September 3, 1711] in The Spectator: A New Edition with Biographical Notices of the Contributors (London: William Tegg, 1866), 182.

25 This thesis was put forward by Wolfgang Welsch in an article: Wolfgang Welsch: "Filozofia i sztuka - wzajemne relacje. Tematyka i cel" in Estetyka poza estetykq. O nowq postać estetyki (Kraków: Universitas, 2005). For an English version of the corresponding conference lecture see: Wolfgang Welsch, "Philosophy and Art - an Ambiguous Relationship" in Aesthetics and Beyond (Changohun: Jilin People's Publishing House, 2007).

26 Wystan Hugh Auden, "Genius \& Apostle" in The Dyer's Hand and other essays (New York: Vintage, 1968), 436. 
Shelley assumed that a poet and a man are two different natures; although they coexist, they can perfectly well be ignorant of each other and incapable of influencing their corresponding faculties and intentions ${ }^{27}$. The concept of the artist reaches beyond the presupposed natural abilities of a human being. The artist's unique status results from transcending human limits and defeating the dichotomies that philosophical inquiry could not overcome. From the groundwork of German philosophical tradition arose a concept of a remarkable individual that reconciled the divide between reason and nature, the conscious and subconscious, the sphere of freedom and necessity. From the aesthetics of Friedrich Schelling, Jean Paul Richter, also Goethe and Friedrich Schiller, comes a new theory of inspiration. The category of the "unconscious" is used to describe the dark side of the creative process, which defies comprehension by the artist himself, as well as by others. The suddenness, contingency and involuntary fortitude intrinsic to the act of creation determine the existence of the artist as influenced by the act of divine power or a natural instinct.

Three basic components of the concept of genius, which reoccur in the deliberations of artists themselves, as well as art critics and philosophers, in the course of the seventeenth through the nineteenth century are creative power or creative drive; the crossing of the existential boundaries defined by human nature; the aporetic dimension of the creative process (mystery, serendipity, whim).

In the nineteenth century the transition from a metaphysical to a psychological interpretation of the creative process allowed to treat art mostly as a template of the artist's personality. A growing focus on what Carlyle described as "individual peculiarities" of the author has significantly altered the concept of genius.

The changes within aesthetics at the time of modernism's second wave (1850-1912) ${ }^{\mathbf{2 8}}$ were determined by a specific duality of tendencies. On the one hand, the individual, who creates his identity by constantly differentiating himself from the ever-self-unifying world, sees his status in society rise. Novelty and originality become values in both anthropological projects and aesthetic theories. On the other hand, there are those concepts that would have the artist's personality wiped clean from the work, be it canvas or paper. The emergence of this process, described as the phenomenon of depersonalization, is traced by literary theorists to the works of Baudelaire and

27 See: Percy Bysshe Shelley, Shelley's literary and philosophical criticism, ed. John Shawcross (Folcroft: Folcroft Library Editions, 1977).

28 Hans Robert Jauss, "The Literary Process of Modernism from Rousseau to Adorno", Cultural Critique 11 (1988): 27-61. 
Flaubert ${ }^{29}$. The evident intention to differentiate between the empirical "I" and the textual "I" within the personal documents of both writers delineates a pivotal moment in the aesthetics of modernist literature. The depersonalization of Baudelaire's lyric poetry, as described by Hugo Friedrich, was conceived as a gesture of an anti-Romantic Romanticism, the choice of the "sensibility of imagination" over the "sensibility of the heart" ter written by the author of The Flowers of Evil on the "deliberate impersonality of [his] poetry" resonates with the writer's idiosyncratic confession: "My task is extrahuman"31. According to Friedrich, who constructs a structuralist description of contemporary poetry, depersonalization will become one of the crucial components of twentieth-century poetry in both of the variants identified by him: the line of Rimbaud and the line of Mallarmé.

The "departure of the author" in literature is commonly exemplified by Madame Bovary, the "first modern novel", together with Flaubert's well-known confession exposing the author's intention of choosing such a form of narration that would allow him to exist within the work in the same way God exists within the universe - omnipresent and concealed at the same time.

It is worth noting that the analogy that Flaubert's concept and his vision of the modernist novel are based upon has an interesting tradition. Shakespeare's genius was a subject of a fierce discussion that went on for many decades of the eighteenth and nineteenth century. The two primary theories explained it by employing either the concept of radical subjectivity or objectivity. In the second case Shakespeare's presence in each and every text, and each and every character, created an impression of a certain de-corporation, shedding of any noticeably personal attributes commonly ascribed to a single auctorial entity on the basis of a unified style. There is a fine line between this kind of thinking and the questioning of the very need for the existence of the author of Hamlet. This proves the point that the problem of "the dehumanization of art", that caused José Ortega y Gasset so much anxiety and inspired his well-known essay from 1925, is much older than avant-garde art. Nevertheless, it is the art of the first decades of the twentieth century that by means of its radicalism became an extraordinary amalgam of contradictions, a space of conflict between the polarized aesthetic traditions, which gained representation through the anthropological and social dimension of art. This

29 An apt description of this tendency is presented in Ryszard Nycz, "Osoba w nowoczesnej literaturze: ślady obcości" in Literatura jako trop rzeczywistości: Poetyka epifanii w nowoczesnej literaturze polskiej (Kraków: Universitas, 2001), 50-87.

30 Hugo Friedrich, The Structure of Modern Poetry: from the mid-Nineteenth to the mid-Twentieth Century (Evanston: Northwestern University Press, 1974). 
kind of genius, one who spells his own doom, will turn out to be a particularly appealing model for many artists of this generation.

\section{Avant-Garde Narratives of the Artist. The Anti-Anthropocentric Tradition}

A closer look at the best known manifestos of the European avant-garde, from the early years of the twentieth century, reveals that no matter how much their aesthetic programs differed, they all took up the fundamental problems of the human condition. Into the typical discourse of such texts, future-oriented and postulatory in nature, a new anthropological project was being inscribed a project of an active citizen of the art world. It addressed both the artist and the spectator, as in avant-garde art both parties enjoyed a new-found equality. They were connected primarily by their shared experience of connection to the present moment, the time of technical revolutions and rushing civilization. The new man, like Athena sprung from the head of Zeus, emerged from the "wonderfulness of contemporary life".

The modern world of constructors and catastrophists, naive optimists and melancholic pessimists was founded upon the experience of change, breakthrough and disconnection. The spirit of the age spoke in many tongues, but there was a common impression of the moment's grandeur and a conviction of being witness to the birth of a new man.

Both the Dionysian divisions of European modernism (futurism, Dadaism, cubism) and the Apollonian ${ }^{\mathbf{3 2}}$ fractions have placed freedom on their banners. Giovanni Papini declared in his artistic credo: "I am a futurist, because futurism equals absolute freedom"33. The liberation of art meant both liberation from the past, tradition, convention, cultural institutions, the demands of the public, as well as liberation towards a certain concept of the Artist - a new synthesis of the All-too-human and the inhuman. Especially the exploration of the "inhuman" will be a calling for all exceptional individuals, as expressed in Guillaume Apollinaire's words: "Above all, artists are men who wish to become inhuman"34. This thought returns in numerous avantgarde manifestos, and its importance and inherent ambiguity require deeper reflection.

3

These terms are employed for the purpose of describing the dichotomy of European Modernism by, i. a.: Edward Możejko, "Modernizm literacki: niejasności terminu i dychotomia kierunku" Teksty Drugie 29/30 (1994): 26-45.

33 Gian Battista Nazzaro, Introduzione al futurismo (Napoli: Guida, 1973), 69.

34 Guillaume Apollinaire, The Cubist Painters, trans. Peter Read (Berkley: University of California Press, 2004) 9. 


\section{Futurism or Abandoning the Center}

"Our renewed consciousness does not permit us to look upon man as the center of universal life" - the Italian futurists tried to convince us in their 1910 Manifest ${ }^{35}$. Here the idea of modern anti-humanism equals the deposition of man, he is finally relieved from the central position that he occupied in the world from, at least, the beginning of the modern era. The creations of the human mind, the technical achievements, machines as the heroes of civilization's technological advancement will shape the ideal according to which the part that man is supposed to play in the world is determined. One of the artist's tasks is to praise the might and glory of these creations:

The artist must praise the machine, which is a synthesis of every great intellectual striving of modern civilization; this new, almost human living body, which constitutes an ingenious multiplication of the human body; the machine, which being a product and consequence of human effort, itself produces an infinite number of consequences and modifications to our accompanying sensations and daily life ${ }^{36}$.

The artist is thus a creator of dithyrambs in praise of the progress civilization, of a new co-existence between the steam-engine and the greasesmeared mechanic, he is the herald of the modern Icarus, who flies on the wings of airplanes, of the joyful arsonists and the roaring engines. The artist must possess a sensibility to the dynamic beauty of modernity and an enthusiasm for all of its manifestations. The machine is not merely an emblem of the futurist aesthetic and an object of art, it is also a model, a standard and measure for the actions of the new man. The traits Marinetti endowed him with: glorification of life, dynamism, power; equate the futurist conception of man with the Nietzschean Übermensch. The intensification of life transpires through permanent ecstasy, brought on by movement, noise, lightness and velocity. The machine initiates the founding myth of futurism, the myth of a mechanical centaur, the multiplied man. In the article The aesthetics of the machine Marinetti claims that today the machine commences and contains within itself the true drama of humanity ${ }^{37}$.

35 Umberto Boccioni et al., "Futurist Painting: Technical Manifesto (11 April 1910)" in Futurism: An Anthology ed. Lawrence Rainey et al. (New Haven: Yale University Press, 2009), 65.

36 Filippo Tommaso Marinetti, "Estetyka maszyny" in Tomasz Kiereńczuk Od sztuki w działaniu do działania w sztuce. Filippo Tommaso Marinetti i teatr włoskich futurystów (Kraków: Księgarnia Akademicka, 2008), 251.

37 Ibid.,252. 
The negative hero is not only the passéist culture, but also human nature that imposes its rules upon art: the principle of imitation and the contemplative manner. The contemporary man's rhythm of life, the order of perception and activity all acquire from the machine such traits as energy, power, discipline, precision, which allow him to discover new modes of existence. Mario Morasso, the author of La nuova arma - La macchina (1905), that precedes Marinetti's own treatise, prophesies the coming of an era of a new artist:

With pictures that we cannot even imagine, he will be able to show beauty yet unknown to us and reflect the character of new heroes - the mechanical colossi in permanent rivalry. The poet will reach ecstasy, describing metallic utensils that he does not recognize and will shiver at the sight of heroism of man administering this mechanical world ${ }^{\mathbf{3 8}}$.

Marinetti created the idea of a multiplied man, who will become a citizen in the Kingdom of the Machine. This new kind of human being is a specific modification of its predecessor, that will come to life inspired by the process of mechanization and enhancements in the field of medicine. Lamarck's theory revealing the underlying rules of emergence and inheritance of new body parts in response to repetitive and motivated stimuli became one of the fundamental ideas feeding futuristic phantasms. Umberto Boccioni and Aldo Palazzeschi dedicated enthusiastic texts to a French doctor Alexis Carrel, who performed groundbreaking organ transplants in animal subjects ${ }^{39}$. The creative phantom-man was supposed to come to being as a final result of efforts leading to multiplication of energy, will, intelligence and instinct.

The futurist aesthetics in the course of realizing the project of dehumanization created new sets of rules for art at multiple levels of sophistication. One of the most interesting areas of artistic inventiveness of the Italian futurists was the theater, where a revolution, in the traditional theatrical relation between the actor and the spectator, took place. The intellectual energy of the creator is transposed into a kind of a recurring ritual (gymnastic exercises) that induces in the spectator a specific state of hypnosis. This is achieved by means of "dehumanizing the voice", "dehumanizing the face", geometric gesticulation, numerous nonverbal means of communication (sounds of objects), dynamic and synoptic declamation.

38 Mario Morasso, La nuova arma - La macchina (Torino: Bocca, 1905) in Tomasz Kiereńczuk Od sztuki w działaniu do działania w sztuce. Filippo Tommaso Marinetti i teatr włoskich futurystów (Kraków: Księgarnia Akademicka, 2008), 238-239. 
In the new Futurist lyricism, an expression of geometrical splendor, our literary I or ego consumes and obliterates itself in the grand cosmic vibration, so that the declaimer himself must also somehow disappear in the dynamic and synoptic manifestation of words-in-freedom ${ }^{40}$.

Rebellion against the sentimental aspect of passéist art leads to the castration of human feelings, passions, affects and envies (they reduced eroticism, filled with characteristic misogyny, to a series of brief, mechanical acts). In turn brutality becomes appraised: "art, in fact, can be nothing if not violence, cruelty, and injustice".41 This means that the artist abandons those fertile areas that until now provided traditional and satiating nourishment for art. The artistic identity looks for aesthetic stimulation on the antipodes of anthropocentrism.

\section{Artists Against Art. Dada - the Radical Rebellion}

The first decades of the twentieth century saw a radical stance of contestation take hold within the avant-garde. Its subject, scope and methods became the defining trait of particular movements; but its most severe form is to be found in the Dadaist movement. An anti-aesthetic stance taken by the artists constituting this group was directed against bourgeois culture, which - according to them - made art in its own measure and consumed it strictly for its own pleasure. Dada - in the words of the Dada Manifesto - meant most of all a "state of mind" undergoing constant rebellion ${ }^{\mathbf{4 2}}$. This was a firm rebuttal of the traditional understanding of a work of art as an autonomous aesthetic object that is based on predefined canons of beauty and perfection, and the vision of an artist as an individuality distanced from the mundane concerns of ordinary life and the common public, by means of his socially sanctioned talent. "[...] Life that strives upward by negation. Affirmation-negation: the gigantic hocus-pocus of existence fires the nerves of the true Dadaist" 43 . The rule of contradiction became the sole principle that appeared on the horizon

40 Filippo Tommaso Marinetti, "Dynamic and Synoptic Declamation (11 March 1916)" in Futurism, 220.

41 Filippo Tommaso Marinetti, "The Founding and Manifesto of Futurism (20 February 1909)" in Futurism, 53.

42 Richard Huelsenbeck, "Collective Dada Manifesto (1920)" in The Dada Painters and Poets: An Anthology, ed. Robert Motherwell (Cambridge: Belknap Press of Harvard University Press, 1989), 246

43 Huelsenbeck, "Dada", 246. 
of life perceived as chaos, "a simultaneous muddle of noises, colors and spiritual rhythms". Such a view of the world and art as devoid of any limitations was at the source of a realization that anything can become a work of art, and anybody can become an artist. An arbitrary object, either found or manufactured, under certain conditions acquires the status of an aesthetic object (objet trouvé, ready-mades, collages, photo-montages). And the identity of the artist is not that of a man marked with a stigma of genius. O ne is not an artist - one only happens to be an artist, it is a part that one plays incidentally and for a brief time, although intensely - in aura of provocation, ridicule, and scandal.

The nascence of this idea caused a fundamental reevaluation of two basic categories: of the artist and the work of art, and was a sign of a crisis within the old and a beginning of a new aesthetic awareness. Nevertheless, its meaning is obscure even in the declarations of artists themselves. Specified and developed in numerous programs of countless creators and artistic groups, it projects a multitude of possible meanings.

The utopian dream of a radical break with the old and the beginning of new art was shared by all avant-garde artists. Nevertheless, even the greatest rebels often merely repeated the gestures of their predecessors. The Dadaists played their parts by masterfully performing gestures already honed to perfection by their nineteenth-century antecedents. The whole affair of absconding in the middle of war, battles, and bloody massacres of the year 1916, and creating in neutral Switzerland a "Cabaret Voltaire", was a truly extravagant maneuver in the best spirit of decadent escapism. Both in the case of the decadent and avant-garde artist the voluntary isolation, that fueled the intense creative practices, was meant to be a sign of disagreement with the process of technical modernization and a critique of nature's influence on the formation of aesthetic rules. The basic difference between these two generations is exhibited by the early twentieth-century artists' compulsive need for collective actions, the obligatory participation of spectators and in the madness proportional to the insanity of the world engulfed by war - inventiveness liberated from all rules. The meeting of Romanians (Tristan Tzara, Marcel Iancu), an Alsatian (Jean Arp), Germans (Hugo Ball, Richard Huelsenbeck), a Frenchman (Robert Delaunay) and the "Parisian" Spaniard (Pablo Picasso) in the earth-bound, bourgeois Zurich was the beginning of the "anti-artistic" anarchism.

The Dadaist proclamation of freedom culminated in an almost self-destructive ecstasy: "To be against this manifesto is to be a Dadaist" 44 . The image of a Dada inventor constructing a machine that as its purpose has the destruction of the creator himself, resurfaces in artistic comments of those

44 Huelsenbeck, "Dada", 246. 
times. Art becomes the artist's enemy (Arp: "the Dadaists despised what is commonly regarded as art, but put the whole universe on the lofty throne of art"45), the Dadaist shies from becoming an artist, he champions life, action. This presupposition often resulted in artistic futility. Jacques Vaché's - the Paris avant-garde's dandy - "good fortune is never to have produced anything. He always kicked aside works of art, the ball and chain that retains the soul after death" ${ }^{46}$. Duchamp in hindsight judged the Dadaists' actions in the following way: "the Dadas were truly committed to action. They were not just writing books, like Rabelais or Jarry, they were fighting the public. And when you're fighting you rarely manage to laugh at the same time"47.

This is the version of Dadaism, where the race towards some infinite freedom culminates either in self-destructive nihilism or in the abyss of catastrophism (some futurists also shared this fate). The idea of an avant-garde artist at the same instance encompassed everything and nothing.

This sort of negation of art, in the subsequent stages of the avant-garde movement, led artists to commit "suicidal" gestures. The conviction that art died in the face of the frenetic explosion of technical civilization and mass culture, led to a drastic restriction of artistic communication, to the point of different kinds of "withdrawal".

\section{Contradicted Identity: Now Everyone is an Artist}

The avant-garde anti-art implied an image of the artist whose actions are guided either by the intellect or by instinct. Whatever the case may be, creativity is not an entelechial process, with some distant goal of producing a work of art, but depends on the intention and will to act. The transition from the aesthetics of the work of art to aesthetics of action became one of the crucial indicators of the shift within the aesthetic paradigm.

This archetype of the artist was closely connected to specific concepts of the 'self', which were coming to prominence in the first decades of the twentieth century. The abandonment of the essentialist paradigm of identity that changes in a linear fashion, in favor of a subject undergoing fragmentation, disintegration, that adheres to the rule of contingency and inner tearing, influenced the change in the image of a creative individual. Often perceived as an anonymous "man of the crowd", who performs random actions, with

45 Calvin Tomkins, Duchamp: A Biography (New York: Henry Holt, 1996), 191.

46 Andre Breton, The Lost Steps, trans. Mark Polizzotti (Lincoln: University of Nebraska Press, 1997), 52-53. 
their presumed aesthetic aspect of a non-intentional and immediate nature. Huelsenbeck wrote in his manifesto:

Dada is a state of mind that can be revealed in any conversation whatever [...]. Under certain circumstances to be a Dadaist may mean to be more a businessman, more a political partisan than an artist - to be an artist only by accident - to be a Dadaist means to let oneself be thrown by things, to oppose all sedimentation ${ }^{\mathbf{4 8}}$.

The claim that creative action is merely one in a multitude of human activities revealed not only a break with the traditional status of that individual previously referred to as the artist. It also implied the presupposition that any human being can become a subject performing creative action.

This idea was developed exceptionally rapidly in the context of opinions that emphasized the democratization of art and the universal character of human nature.

The rejection of the autonomy of art called for by many avant-garde artists resulted primarily in the interweaving of artistic practices into the fabric of social life. This corresponded with the leftist convictions expressed by numerous artists. Introducing art to the general public was supposed to be a way of erasing boundaries between spheres of artistry, utilitarianism and entertainment. The public arena became a fertile ground for executing artistic actions that were tailored according to her special needs, and the style of this activity explicitly refers to the rules of mass entertainment.

Polish artists, following in the footsteps of their West European colleagues, will proclaim that: "Art must only and mostly be human, that is for people, for the masses, it is to be democratic and common", so "Artists to the streets!" 49. At the same time, in a paradoxical twist, the democratization of art results not only in broadening and equalizing the base of its recipients, but also of its creators, everyone claims the right to be considered an equal creative subject ("Anybody can be an artist"50). The notion of an artist becomes an element of a mythical reality in a revolution made according to the principles of world

48 Huelsenbeck, "Dada", 246.

49 Bruno Jasieński, "Do narodu polskiego: Mańifest w sprawie natychmiastowej futuryzacji żyća" in Stanisław Jaworski, Awangarda (Warszawa: Wydawnictwa Szkolne i Pedagogiczne, 1992), 187.

50 Jasieński, "Mańifest", 188. This idea will return in the manifestos of the neo-avant-garde, most visibly in the well-known Joseph Beuys interview from the year 1972, who declared that everyone is an artist, because "every capacity comes from the artistic capacity of man, which means, to be active, creatively". 
"à rebours" (Peiper: "The greatest poet of the revolution is a baker"51). The enthusiasm for the frenzy of civilization that overwhelmed everybody at the time is clearly audible in these futuristic exclamations.

\section{An Artist Without a Biography}

"What has been done in the name of self-improvement is completely irrelevant" - states George Grosz at the end of his essay In place of biography (1925). The avant-garde artist's renouncement of his own biography was just another gesture of contestation. It was directed against two movements within the traditional nineteenth-century concept of art; the first one was the institutionalized cult of the artist that has become a distinct cultural phenomenon. The artist's authority was constructed from a number of components: secretiveness, extravagance, occultism and wizardry, truth and wisdom, perfection of craftsmanship. The other target was biographism in its academic form, which explored either the expressive-emotional or cognitive-didactic aspect of a work of art. In the programs and manifestos of the first three decades of the twentieth century, that exhibit strong leftist tendencies, both these arguments will be used in the attack on bourgeois society. In extreme cases of truly radical artists, such as Grosz, for whom an ideal creator was a "sharp and healthy worker of the collective society", a biography consisting of "unimportant, accidental, external events" $\mathbf{5 2}$ was pointless.

In the proclamations of Italian and Polish futurists the matter of the artist's biography becomes even more complicated. Marinetti, criticizing the psychologism of passéist art, distinguishes its three forms:

1. Traditional scientific-documentary psychologism.

2. The Parisian sort of semi-Futurist, fragmentary, effeminate, and ambiguous psychologism (Proust).

3. Italian psychologism, which dresses up its enormous, pettifogging, ponderous, funeral, moralistic, academic, pedantic analyses as Futurism, with their associated decrepit Hamletisms: "To be or not to be; live, dream" and philosophical dialogues which have no tangible concern or dramatic pacing53.

51 Tadeusz Peiper, "Także inaczej" Zwrotnica 7 (1926): 198.

52 George Grosz, Wieland Herzfelde, Die Kunst ist in Gefahr: Drei Aufsatze (Berlin: Malik Verlag, 1925), 39-44.

53 Filippo Tommaso Marinetti, "The Abstract Antipsychological Theater of Pure Elements and the Tactile Theater" in Filippo Tommaso Marinetti Critical Writings, ed. Gunter Berghaus, trans. Doug Thompson (New York: Farrar, Straus and Giroux, 2006), 390. 
The psychologism of old art is to be replaced by "body-madness", as he declares in a manifesto "The Variety Theater", from the year 1913.

Bruno Jasieński, without the semantic inventiveness - but with sheer force, posits severing new art's relationship with the soul, God and universals, replacing them instead with sport, sex and mathematics:

Our art is neither a resemblance, nor an anatomy of soul (psychology), it isn't an expression of our longing for the kingdom of God (religion), it isn't a discussion of eternal questions (philosophy). [...] The artists experience is his own. It is undoubtedly fascinating for his immediate family and admirers, but for nobody else. It is advisable that the artist channels and relieves his inner pressure in the proper manner, by taking up sports, through carnal love and a pursuit of formal science ${ }^{54}$.

The spirit of the time speaking through the voices of art historians (Wölfflin: history of art without names), literary theorists (Russian formalists) and artists, proclaimed a new image of the creator. German aesthetics and Russian literary theory have adopted the assumptions of anti-psychologism and anti-biographism as cornerstones of proposed methods of scientific inquiry focused on the formal dimension of the artifact. When artists decided to state their opinions on the subject, the discussion took an unexpected turn. The artist's persona retained its former importance, but its public reception underwent a radical change. Similar to the case of the work of art, dynamic activity and creative invention also dominate here. The creative personality is inscribed into a complete aesthetic project and becomes subjected to the same principles that rule the art world. The notion of the artist encompasses the avant-garde triad of "life-art-vitality". New art, being a "synthetic expression of cerebral energy", "symphonizes the audience's sensibility by exploring it, by reawakening its most somnolent layers with every possible means"55. The idea of an "artist without biography" de facto implies a farewell to the anachronistic understanding of identity: "Fate outlived itself and died. From now on anybody can become a creator of his own life and of life in general"56. The avant-garde vision of the artist brings into the limelight the persona of a selfcreating creator.

54 Bruno Jasieński, "Jednidniówka futurystów" in Jaworski Awangarda, 194-195.

55 Filippo Tommaso Marinetti et al., "The Futurist Synthetic Theater (11 January 1915)" in Futurism, 208.

56 Jasieński, "Mańifest", 190. 


\section{Leonardo da Vinci - The Avant-Garde Genius}

The avant-garde's disrespect for man's greatness, its praise of the masses, and the anonymity they offer, is one of its particularly distinctive features. The avant-garde artist's identity formed in accord with a declared feeling of community. Knocking works of art and geniuses off their pedestals became a gesture of self-definition. Exceptional individuals seemed to be an anachronistic phantasm of bourgeois society. In this context it is worth to refer to the paradox which was formulated by George Steiner in relation to the ancients: "It is just because the chaotic and the demonic were so vivid to ancient Greek sensibility that such energies were invested in order"57. Modernist philosophers stated that fascination with the phenomena of disintegration and coincidence is a consequence of an extraordinary sense of continuity and synthesis. The fantasy of producing a total work of art has been expressed in numerous visions of avant-garde artists, by among others: Kandinsky, Apollinaire, Schwitters. Both Picasso and Matisse "in their undisguised striving after futurity, after the consecration of the museum or the pantheon, these painters are disciples of Giotto"58. Several anthropological projects are logical outcomes of aesthetic ideals: Marinetti's multiplied-man, or Artud's total man. Frequently a specter of genius accompanies the avant-garde artists' journey through the valleys of a dehumanized world. Let us take a closer look at one aspect of the avant-garde mythology of genius, interpreted, as Steiner proposed, as the narrative of the modern artist's formal experience.

When he defined the area of anti-tradition Guillaume Apollinaire mentioned, in his well-known futurist manifesto, among others: Dante, Shakespeare, Goethe, Wagner, but omitted Leonardo da Vinci. Is it a coincidence? It most certainly is. Futurists seemed to strike at random. However, can we plausibly assume that he, whom European culture worshiped as its greatest genius for four hundred years, has been abandoned at the ash heap of history, together with the museums and the academia?

This just seems not to be the case, and having one particular event in mind, we can assume that Leonardo is a patron saint of the European avant-garde movement.

On 21 September, 1911 Vincenzo Peruggia steals the par excellence European (that is non-Italian) masterpiece of Leonardo da Vinci - The Mona Lisa - from the Paris Louvre. The particular effect this event has had was based on the force with which it unveiled the ferment that has for quite some time been steadily growing in the aesthetic tastes, norms and values, affecting not as

57 George Steiner, Grammars of Creation: Originating in the Gifford Lectures for 1990 (London: Faber and Faber, 2001), 42.

58 Ibid., 273. 
much the area of academic aesthetics, as the sphere of cultural functioning of art. Some considered the wide interest the painting's disappearance has generated to be a proof of the visual arts' unwavering popularity, particularly of their sanctified masterpieces. Others saw in the empty space of the museum wall a prophetic mark left by the spirit of the time.

And the spirit of the time bellowed through the thoughts of Marinetti, Apollinaire and Artaud: "Away with masterpieces!" Curses muttered by the avant-garde artists from the beginning, have finally materialized: Mona Lisa disappeared. The day following the painting's theft Apollinaire, unsuspecting yet that he himself will soon become a suspect, wrote in an article:

"La Gioconda's beauty was so great that her perfection granted her an enduring place among masterpiece-trifles. And there aren't so many of those. Apollo Belvedere, Venus de Milo, Sistine Madonna, The Last Judgment, The Embarkation for Cythera, The Angelus, Isle of the Dead - this is almost everything that humanity has set aside from centuries of artistic effort"59.

No wonder that in the stretch of time between its theft in 1911 and its recovery in 1913, a heated debate elevated The Mona Lisa to the rank of an icon of high art. It became a synecdoche for great West European art. Leonardo's masterpiece was dematerialized in a twofold sense - the purely physical and the symbolic. The blankness of the Louvre wall terrified spectators with its remaining hooks, and the long lines forming before it were proof that the museum has become, as an institution, a kind of perpetuum mobile, capable of functioning without artifacts, replaced by the miasmal aura of an exhilarating aesthetic experience. The provocative questions of why has this "mere object of trade" (as the cynics commented) been given so much value, led to serious deliberations upon the mechanism of creating cultural value, and revealed a strong need for its demystification.

The painting's theft generated a whole series of cultural gestures made in jest: from satirical caricatures, parodies, press humor, cabaret songs, even short-films; to serious, desecrating comments. This is the period when, according to Donald Sassoon, the author of a monograph about Mona Lisa, a fashion for ridiculing high art in popular culture began ${ }^{\mathbf{6 0}}$.

59 Mieczysław Porębski, Granica współczesności 1909-1925 (Warszawa: Wydawnictwo Artystyczne i Filmowe, 1989), 35.

60 Donald Sassoon, Mona Lisa: the History of the World's Most Famous Painting (London: HarperCollins Publishers, 2001). 
The reflected light of La Gioconda's extraordinary fame also shone on the avant-garde artists. During the agitated discussion that ensued in the press, in one of the Louvre's director's caricatures there appeared, for the first time, a mustachioed Mona Lisa. Subsequent reproductions of Leonardo's painting enhanced with masculine facial hair, by such renowned artists as Picabia, Duchamp and Dali, have been considered to be among the most consequential provocations in the history of twentieth-century art. Have these gestures of degradation of a work of art come as a result of disenchantment with the era of geniuses? For Marcel Duchamp this puerile gesture will become a gateway to fame in Europe and the United States. The rebellious Dadaist will soon evolve into a rational manager, who with the aid of a New York notary will ensure for himself the copyright to the attached mustache, and beard. But the very act of toying with the masterpiece will absorb Duchamp so deeply that many years later he will attempt to emulate the original act. During the 1965 American retrospective of the artist, the invitation to the event was designed in the form of a playing card depicting Mona Lisa, sans mustache, with the inscription $L H O O Q$ rasée (shaved). Thus Leonardo's painting became a caricature of Duchamp's work; Da Vinci was knighted as a permanent artistic interlocutor of the avant-garde genius.

Duchamp's interactions with the painting shared a common theme that directly referred to both of the artists. The added facial hair was a sign of the depicted person's sexual identity - hermaphroditism was supposed to be Mona Lisa's secret. Popular literary interpretations of the painting's mystery implicated Leonardo himself. The most popular of the Renaissance artist's biographies, Dmitry Merezhkovsky's ${ }^{61}$ trilogy, suggested that the myth of androgyny is the key to Lisa Gherardini's portrait, which in fact is a portrait of Leonardo himself. It is a well-known fact that one of Duchamp's great fascinations, the sexual ambiguity of his own nature hermaphroditism and transvestism, became a creative impulse for many photographic self-portraits and numerous performances. Duchamp owes his discovery of the connection between the androgenic theme and Leonardo's person to the reading of Sigmund Freud's study from 1910 - Leonardo da Vinci and a Memory of his Childhood.

Freud's text succumbed to the aura of avant-garde provocation, which while berating tradition simultaneously praised it. The creator of psychoanalysis was fully aware that entering the art world with his psychoanalytical apparatus spelled destruction to the sublime persona of the Renaissance genius. He appealed to the reader:

61 Dmitry Merezhkovsky, The Romance of Leonardo da Vinci (New York: Random House, 1931). The titles of subsequent parts are The Death of the Gods. Julian the Apostate; Peter and Alexis. 
I hope the reader will restrain himself and not allow a surge of indignation to prevent his following psycho-analysis any further because it leads to an unpardonable aspersion on the memory of a great and pure man the very first time it is applied to his case ${ }^{62}$.

He assumed the hermeneutic value of the artist's "pathographical" portrait to be so high, that even if the amount of speculation and fantasy contained within it was so extensive to merit the accusation of being a mere "psychoanalytic novel", it was still worth the effort.

Freud achieved two goals: he took Leonardo's virtue from him, and gave him a body instead. The persona of the Renaissance artist that has become so idealized by the late nineteenth-century cult of sublime genius, revealed before the twentieth-century public its most intimate physicality. Freud's thesis that the creative process has a corporal aspect, led to the conclusion that an analysis of the artist's sexuality will bring a better understanding of the mechanisms influencing creative decisions. The ingenuity of the creator lost the dimension of a spiritual mystery, its secret revealed as mere coincidence that rules all nature. The discovery of rules governing the human psyche is accompanied by a descent into the abyss of contingent existence. Freud ends his study: "at the same time we are all too ready to forget that in fact everything to do with our life is chance, [...] We all still show too little respect for Nature which (in the obscure words of Leonardo which recall Hamlet's lines) is full of countless causes ["ragioni"] that never enter experience"'63.

These three facts: the painting's theft, Duchamp's artistic games, and Freud's psychoanalytical study, make Leonardo a hero of three distinct types of narration: sensational, artistic and aesthetic. The public opinion in reaction to real and symbolic events, the artistic praxis and the scientific-philosophical reflection, produce a multidimensional cultural object, which Leonardo becomes as the avant-garde's genius.

From the vantage point of the artist's reflections upon artists, at that time, things look significantly different.

The image of Leonardo that emerged from numerous comments of avantgarde artists became a special kind of mirror, reflecting the presuppositions of contemporary creative individuals. The variety of avant-garde movements, of which many have designated Leonardo as their predecessor, is the reason his image resembles a cubist composition, only seemingly forming a singular object. Marinetti in his Sorbonne lecture (1924) named Leonardo the "first

62 Sigmund Freud, Leonardo da Vinci: A Memory of His Childhood, trans. Alan Dyson (London: Routledge, 2014), 35.

63 lbid., 96-97. 
great futurist"; Albert Gleizes and Jean Metzinger, in their 1912 book Cubism, designated Leonardo to the post of public defender of the new movement's program. The painter of the Lady with the Ermine can be found in fauvist manifestos (Henri Matisse) among accepted authorities on painting. Salvador Dalí's Diary of a Genius features, besides its main hero of course, another important supporting character - the Renaissance genius. At the same instance Leonardo is a futurist, a fauvist, a cubist and a surrealist, that is to say - a synthesis of the European avant-garde. Some of these occasional references are merely an exhibition of self-aggrandizing rhetoric, addressing the honorable precursor. The important aspect of the matter is that the Renaissance master's persona exists not only within the realm of historic reconstruction, but in the self-creating acts of contemporary geniuses.

The most compelling of all modernist portraits of Leonardo can be found in Paul Valery's two essays, Leonardo and the Philosophers and the Introduction to the Method of Leonardo da Vinci. They are both examples of a thorough analysis of the ingenious artist's phenomenon, and at the same time a kind of aesthetic manifesto that will be developed and expanded by the author of Eupalinos in the following decades. The later of these texts, which was written in $1894-$ shaped the perception of the Italian Renaissance artist in the eyes of the avant-garde's representatives, at the start of the twentieth century.

It is notable that the artistic matter, which constitutes the main object of analysis, is not some particular visual masterpiece of Leonardo's, but his judgments, the speculative aspect of his art. Thus, Leonardo the writer of A Treatise on Painting becomes a hero - this is a noticeable shift in the discourse of the transmission of cultural tradition. And the presence of a robust literary code of the visual arts' representation within European modernism cannot be ignored. The description of The Mona Lisa given by Walter Pater, as part of his essay on Leonardo from 1869, also included in his 1873 Studies in the History of the Renaissance, has shaped the way of looking at images, and the narrative style used to describe them, for several decades. As far as in 1936 William Butler Yeats reprinted this fragment, in his introduction to the Oxford Book of Modern Verse 1892-1935, reshaping Pater's prose into free verse form. The poetic ekphrasis, that was a crucial narrative dominant used for describing art of past ages, lost its power with the passage of time.

Valéry follows a different path: he abandons the description of the works and tries to comprehend the very phenomenon of genius instead. He is not interested in the perfection of craft, but is fascinated by "passionate thinking" (Arendt's term), that unifies thinking and being. Leonard"s famous phrase l'arte è una cosa mentale perfectly resonates with the conceptual denomination within the avant-garde movement. The debate, initiated by the Dadaists, on the role of artistic intent as a cornerstone constituting the work of art and all 
other artistic practices, defined an entire period - from Duchamp's Fountain to conceptual art.

Valéry places self-awareness at the center of his model of an exceptional individual, and he attempts to discern the underlying "model of the continuity of the intellectual operations"64. He is fascinated by the "psychic experimentation" constantly occurring in the ingenious mind, that progresses from architecture to general physics and mechanics, from "forms, born of movement, there is a transition to the movements into which forms may be dissolved"65. There is a proposition in Extraneous Remarks that has its roots in the same problem that Freud grappled with: the peculiar entropy of the creative drive, that is the reason behind an inability to complete works of art and the compulsion to begin them anew:

To finish a masterpiece means to erase any trace that reveals or even suggest work. An artist should, according to this antiquated view, make himself manifest only by his style and should continue his labor until it has effaced all trace of labor. But considerations of the moment and of personality having slowly triumphed over those devoted to duration and the work itself, it has come to seem as if finish were not only useless and troublesome but even a hindrance to truth, sensibility and the revelation of genius $^{66}$.

The conjoined opposites of continuation and experimentation, and also frailty, that contradict personal truth - those are components that make up the image of an artist, as an aporetic construct. L'uomo universale transcending the boundaries of art, technology and science through his inventiveness - that is a result of freedom - this is the modernist dream. It is noticeable in avantgarde anthropological concepts, and visions of a total artwork.

Valéry's essay is not just another aesthetic manifesto. The undertaken attempt of defining Leonardo's phenomenon is, as Kristeva would say, a phase of "narrated action". The next stage would be the "acting narrative" - this is a key to reading Valéry's Mr. Teste stories.

Describing his own vision of the wanderings of a great mind, for whom feelings of freedom were a source and direction in leading a creative life, he

64 Paul Valéry, "Introduction to the Method of Leonardo da Vinci" in Paul Valery: An Anthology (London: Routledge \& Kegan Paul, 1977), 90.

65 lbid., 86,54

66 Paul Valéry, Degas. Manet. Morisot, trans. David Paul (Princeton: Princeton University Press, 1971), 20-21. 
reaches the conclusion that the logical consequence of experiencing such freedom must be the rational decision to limit it. From the vision of an ingenious, voracious mind, which in its insatiable drive toward understanding and creating, inspired by the daemon of analogy, consumes everything and everyone; to the ideal of freedom personified in Mr. Teste enclosed within the four walls of his "impersonal" room. The creation of Edmund Teste, the most mysterious of literary heroes that came from under Valéry's pen, is a vision of a perfect mind that exists in extreme asceticism, removing subsequent fields of experience that life offers. Devoid of any ostentation or wonder, this genuinely is a new kind of genius. Lacking cheap exaltation, and free from the original sin of those seduced by self-love and fame, he embodies a straightforward, anonymous extraordinariness. A man that comprehended "human plasticity", was a being "absorbed in his own variations, one who becomes his own system, who commits himself without reservation to the frightening discipline of the free mind"67. This genius, picked for his own use by the onlooker and narrator from an anonymous crowd, elicits enthusiasm and shock, he fascinates and terrifies, until he disappears completely in the compassion that the vision of Mr. Teste's suffering induces in the spectator: the only mystery, he could not solve, was pain.

The All-too-human and the inhuman constitutes a modern aesthetic aporia, that Valéry tried to address using his own "sequence of intellectual operations".

The process of creating a genius, in its subsequent phases: inspiration "food for thought", narrative of creative action, finally "acting out" the artistic myth, had in the case of Valéry, as well as other avant-garde artists, the character of experiencing identity. A particular poetics of self-creation is the foundation of the aesthetic notion of an artist. The relation between the modernist artist and other artists, taking shape in the aura of growing suspicion towards the anthropocentric ideal, often turned into a ritual repetition of the basic question of his own existence.

Translation: Rafat Pawluk

67 Paul Valéry, "The Evening with Monsieur Teste" in Paul Valery: An Anthology (London: Routledge \& Kegan Paul, 1977), 7. 